\title{
PUBLIC WORK - AN INTERNATIONAL OUTLOOK
}

\author{
Imola Cseh-Papp ${ }^{1}$, Troy B. Wiwczaroski², Tünde Csapóné Riskón \\ 1 Szent István University, Faculty of Economics and Social Sciences, Gödöllő, Hungary \\ E-mail: papp.imola@gtk.szie.hu \\ 2 University of Debrecen, Faculty of Economics and Business, Debrecen, Hungary \\ E-mail: troy.wiwczaroski@econ.unideb.hu \\ 3 University of Debrecen, Faculty of Economics and Business, Debrecen, Hungary \\ E-mail: risko.tunde@econ.unideb.hu
}

\begin{abstract}
Labour market policy includes active and passive labour market programmes, aiming to solve different problems. Active labour market programmes assist the unemployed to find jobs and thus return to the labour market. Passive labour market programmes assist the unemployed by providing various kinds of aid, easing social tensions. Public work can be considered to be an active labour market programme, assisting people who receive social care with income based on public beneficial work. Consequently, public work is justified by some on the basis that it is purported to have some kind of moral foundation, as well as because it supposedly shows results within a short time. Yet, the rationale behind using public work programmes to fight unemployment is contested. Detractors see them as being rather costly, questioning their success and arguing that their overall results are uncertain, especially in the long run. In short, there are in fact pros and cons to using public work, with opinions being rather divisive. This study summarises these pros and cons, analysing the relevant international and Hungarian literatures in the context of active labour market programmes.
\end{abstract}

Keywords: : Active Labour Market Programmes, Public Work, Labour Market, Unemployment, Workfare (JEL Classification: 138 )

\section{INTRODUCTION}

The transition period from the centralised redistributive economic system to the market economy between 1989-1991 in the Central and Eastern European countries (post-socialist countries) has been accompanied by a deep crisis which lasted until the autumn of 1993. This recession was much more complex than those common for the declining phase of the economic cycles of capitalist systems, since it cannot be considered as a result of overproduction. It more likely can be traced back to the structural change in the political and economic systems. After the transition period, the full employment of socialist ideology, which had existing for decades, ceased in each country. This change was one of the greatest challenges to the introduction of the market economy. The new structure of employment in these countries was less than ideal for the new economic mechanisms, and this disparity has led to the permanent lack of job opportunities in these countries ever since. Considerable differences have appeared among regions after the massive disappearance of jobs, e.g. in the mining industry. Because the state no longer guaranteed full employment by law, labour demand considerably decreased, exacerbating unemployment further, as the labour market underwent the inevitable restructuring throughout the 1990s and beyond. Active labour market programmes were introduced to manage the balance deficit in the labour market (Csehné et al., 2009).

\section{SPECIALTIES OF ACTIVE LABOUR MARKET PROGRAMMES}

The OECD defines active labour market programmes as follows: These programmes include all social expenditure (other than education) which is aimed at the improvement of the beneficiaries' prospect of finding gainful employment or to otherwise increase their earnings capacity. Active labour market programmes help increasing the labour market flexibility during economic changes. The aim of active labour market programmes (labour market services and aids promoting employment) is to help the unemployed return to employment as fast as possible. Expenditures (\% of GDP) in active labour market programmes of OECD countries 
show considerable differences (Figure 1). The more than 2 percentage of GDP in Denmark has been followed by the other Scandinavian countries (1-1.5 percentage of GDP), while the United States, Japan, and the Balkan countries (0.1 percentage of GDP) can be found among those countries investing the least. Hungary, with its 0.8 percentage of GDP, can be found in the first third.

Figure 1: Public expenditure in active (ALMP) and passive (PLMP) labour market programmes in OECD countries in 2016 (GDP \%)

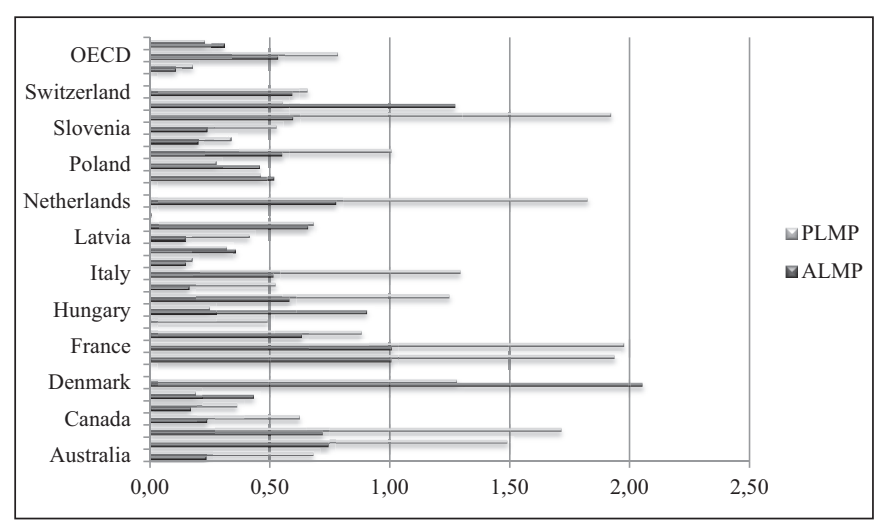

Source: OECD (2016), own editing

Regarding the participant stocks in active labour market programmes (Figure 2), Luxemburg and Spain are the leaders (more than 8 percent of the labour benefits the programmes), while Hungary (5.5 percent), together with Portugal and Sweden, can be found in the first third.

Figure 2: Participant stocks in labour market programmes in OECD countries by category, $2016(\%)$

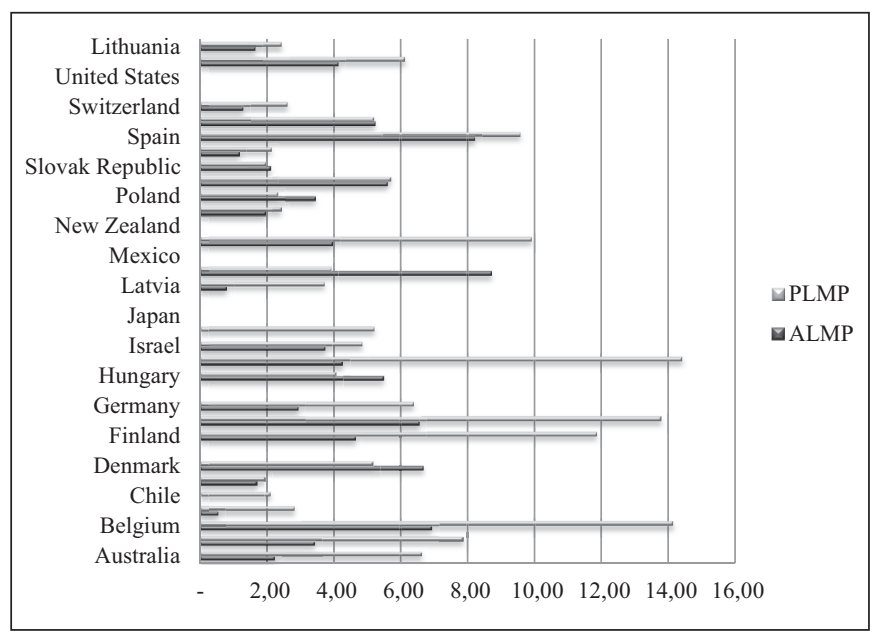

Source: OECD (2016), own editing

Within the active labour market programmes, in 2016, Hungary ( 0.52 as a percentage of GDP) is the leader in spending on direct job creating public work programmes, followed by Ireland ( 0.27 as a percentage of GDP), Bulgaria ( 0,15 as a percentage of GDP) and France (0.14 as a percentage of GDP). The expenditures of Slovenia, Lithuania, Latvia are relatively high (0.07-0.14 as a percentage of GDP). Significant public work programmes are operating in these countries, as well as in Greece.
Based on international experiences, among the active labour market programmes, the more personalised and targeted programmes have more chance to access real results (Martin - Grubb, 2001; Crépon - Van den Berg, 2016). While personal counselling, assistance in job-search, job placement, income subsidisation (roughly in this order) can be effective, public work programmes could be unsuccessful regarding further employment and salary. The effectiveness of training programmes is variable although they are rather expensive (Brown - Koettl, 2015; McKenzie, 2017; Schmidt et al., 2017). After analysing the active measures of the big labour market reform in the 1990s, in Sweden, it has been revealed that job creating programmes can be effective, as they precisely imitate the situation of real employment (Heikkilä et al., 2002; Albæk et al. 2014).

Assessment of the effectiveness of active labour market programmes was carried out first in 1992-1993 in Hungary, within the ILO Japan Programme (Godfrey-Lázár-O’Leary, 1993). Since that time, the monitoring system developed for this purpose has been measuring the cumulated effects of completed labour market programmes. Generally, it can be stated that people receiving active support earlier more likely become members of the supported group again in the second half of the observed period than those belonging to the control group (Csoba - Nagy, 2011).

\section{SPECIALITIES OF PUBLIC WORK PROGRAMMES}

Of the active labour market programmes, public work is one of the oldest programmes and the second most active programme affecting the most people on the Hungarian labour market. Public work has always appeared in Central and Eastern Europe since 1990, whenever economic and employment structures have undergone new changes, because the balance between the labour market demand and supply was broken, generating income shortage and thus necessitating central intervention.

From an ideological point of view, public work can be found in the intersection of two trends. On the basis of the classical approach, it can be considered to be a measure of social policy. From a neoconservative or neoliberal point of view, it is considered to be something akin to being a criminal policy, since through such programmes, the state forces individuals to adopt a mandated way of life (Szabó, 2013).

Several examples prove that large government and council level investments have been carried out by public work. In these cases, public work is not considered as a labour market programme, but as a way through which a certain state or community goal can be reached, although it is functioning as a labour market measure, as well. The American New Deal programme was a response to the Great Depression between 1929-1933. As a result of the Great Depression, masses of people became unemployed, thus the aim of the programme was to provide these unemployed people with jobs and thereby rebooting economic development. The state generated supplementary demand and tried to lower the depth of crisis 
through infrastructural investments, thus providing the private sphere, companies and employees with income (Smith, 2006).

Public work is a forced labour programme set by the state in the 2000s in Europe. A person who is not able to find a job after receiving unemployment benefits can receive a lower sum as a benefit and has to accept the job offered by the state (Csoba, 2010). Only 10 percent of people participating in public work programmes return back to the legal labour market, while this ratio is two times higher among those not attending such programmes. A job requires a regular way of life; the days spent with work are really important in preserving intellectual and physical abilities, although it is doubtful whether constraint can neutralize positive outputs (Szabó, 2013).

The concept of workfare can be found behind public work programmes. There are hot professional debates whether public work is primarily a "constraint and work test" or a kind of corridor to labour market.

One of the aims of workfare programmes is to respond to labour market changes through "active" labour market programmes targeting unemployed people receiving social benefits. Basically, these programmes include measures on the demand-side (job creation, income subsidisation) and on the supply-side (supporting flexibility and the mobility of labour force) at the same time, in order to reduce unemployment (French, British, American examples). In some countries, this measure is more frequently applied for those who have more difficulties with finding a job. For them, some parts of the programme (Danish, Dutch, British, Californian programme) ensure the potential of "education and training" or "social activation". Moreover, the Danish, Dutch, British and American programmes involve "case management" as well, in order to fit the programme to the client. Out of these four programmes, the Danish activation strategy puts more emphasis on long run strategy and human resource development, while mostly the American programmes focus on the earliest labour market participation (Besley - Coate, 1992; Eardley et al., 1996; Grover - Stewart, 1999; Brown Koettl, 2015; Murgai et al., 2015).

Workfare measures focus on reducing the number of benefit recipients in two ways. First, they "select" and exclude those who are working (and receive the benefit unlawfully), or those who are not seeking for a job at all (although it is the prerequisite to be benefit eligible). Through the filtering effect of the programme, the requirements attract only the really needy people, keep away wealthier ones, thus consequently can reduce state administrative expenditures. If the requirements cause such inconveniences (frequent visits to labour centres, compulsory work or even training, etc.) that can lead to the earliest leaving from unemployment status or avoiding having to accept benefits; and the work requested to be done is considerably to be more than eligible people generally would work without intervention, the deterrent effect of the programme will prevail (Kálmán, 2015). Furthermore, they force people to such situations where they can improve their human capital and their chance to get a job. "Workfare" involves such programmes and approaches which are built on the different combinations of these two mechanisms (Heikkilä et al., 2002).
In developed countries, mainly as a response to a certain short term economic crisis, are such programmes applied or - in cases of high unemployment and typically for a short time period - lead the unemployed back to the labour market. In developing countries, they are concentrated in the most disadvantageous settlements, and therefore are already a kind of selection. Also, the offered public work wages are generally lower than the market wages of poor people. Public work programmes provide only few breakout options for cumulatively disadvantaged people (Wulfgramm, 2014; Zieliński, 2015; Douarin - Mickiewicz, 2017).

Public work is increasingly applied in developing countries in poverty reduction as a transition to guaranteed employment, or even self-employment, like in Argentina, Ethiopia and India (Adimassu et al., 2015; Shah - Steinberg, 2015; Ismail, 2016; Rosas - Sabarwal, 2016; Mourelo - Escudero, 2017). The Indian "National Rural Employment Guarantee Act" (NREGA) (later renamed as the „Mahatma Gandhi National Rural Employment Guarantee Act" (MGNREGA)) provides at least 100 days of wage employment in a financial year to every household whose adult members volunteer to do unskilled manual work instead of the unemployment benefit of the Western model. The Mahatma Gandhi National Rural Employment Guarantee Scheme (MGNREGS) programme affecting 54 million households contributed to the reduction of poverty also by indirectly since in those places where many people were affected, agricultural wages increased. Argentina (Programa Intensivo; Trabao, Programa Trabajar; Programa Jefes de Hogar) has been affected since its severe economic situation (1992), where agricultural enterprise development programmes were supported (e.g. irrigation systems development) or there were examples for direct agricultural production through community gardens, as well. Irrigation system development was carried out in small farms lead by a clearly defined social group - needy women - in Ethiopia (Ronconi et al., 2006; Ravi - Engler, 2015). Public work programmes are facing similar problems both on a national (Hungary) and international level.

Based on a quick European analysis, it can be stated that the volume of public work is outstanding in Europe. Public employment was regulated by the Act IV of 1991 after the transition period in Hungary. In the Act, public employment appeared as the synonym of unemployment, a compulsive solution to temporarily ensure the labour market reintegration of unemployed, helping those people who are not able to find job beyond their own fault. There were two declared functions of public employment: firstly, the so-called work test, meaning that if someone refused public employment, the individual was consequently excluded from being registered as being unemployed, secondly providing participants with normal, not subsidised jobs (Galasi - Nagy, 2008).

The work carried out within the framework of public employment intended to develop the social, health prevention, educational, cultural, law and order and transport situation of settlements. Public employment provides social insurance, eligibility to old-age pension and job search service and ensures access and re-access to the primary labour market. 
Public employer can be: local government, budgetary body, church, civil association, social cooperative.

The system of public employment has been changed several times after 1990 in Hungary. The following institutions existed: public benefit employment between 1987-2010, public work programmes between 1996-2010, public aimed work between 1999-2010. There was a considerable change in 2011, since the different forms of public employment created after the transition period has been replaced by the "uniform system of public employment" (Szabó, 2013; Bördôs, 2015). In the heart of these changes, the "work instead of aid" concept can be found. Since that time, the public benefit employment, public work programmes and public aimed work are not existing, they have been replaced by the uniform system of public employment since 1 September 2011 (Bankó, 2015).

The Hungarian public employment programmes serve three goals: social, employment and political. The social goal is to provide long term unemployed people with higher income. The employment goal is to improve the work abilities of participants and hereby leading them back to the primary labour market. It was not a secret goal to reduce illegal work, i.e. employing individuals without reporting them to the requisite authorities and therefore avoiding payment of social contributions or taxes after income. The political goal was to provide support locally and to ease local social tensions.

An average of 30,000-40,000 people were involved in any form of public employment between 1996 and 2006 in Hungary. This number has increased to $60,000-100,000$ since 2009, and has exceeded 130,000 in 2013. The envisaged numbers are 190,000 in 2018, 170,000 in 2019 and 150,000 in 2020 (Figure 3). These figures can be considered high, even in international comparison (http://kozfoglalkoztatas. kormany.hu/).

Figure 3: Number of unemployed and participants of public work

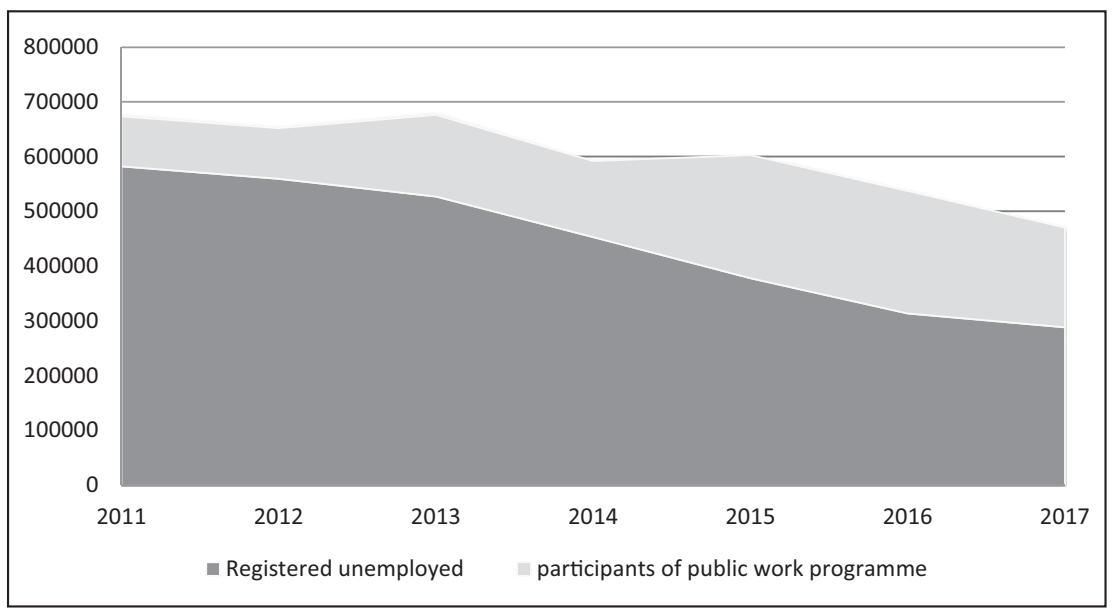

\section{programme
Source: NFSZ, own editing}

In the current system, monthly an average of 200220,000 and yearly an average of 355,000 public employees are involved in the programme. The distribution of affected people is rather unequal, considering the regional distribution of unemployment (the higher the unemployment, the more people are involved in public employment) (Cseh Papp, Csapóné Riskó, 2014).

Regarding the diversity of employers we can find mainly non-profit, construction work and clerical organisations. “NMI Múvelődési Intézet Nonprofit Közhasznú Kft” (nonprofit) was the largest national public employer in 2017 with 2589 public employees, followed by "Magyar Református Szeretetszolgálat" (church) (1959) and "Magyar Közút Nonprofit Zrt." (road construction) (1928 people). They were followed by various regional water management authorities (1200-1700 public employees), “Országos Széchenyi Könyvtár” (public library) (1140) and "Magyar Államvasutak Zrt." (Hungarian railways) (1060). Local governments were also common on the list of public employers.

The most common positions are the following: conveyor, gardener, cleaner, street-sweeper, garbage picker, agricultural auxiliary worker, office assistant and document manager. The latter positions require higher qualifications and are available for graduates.

Regarding the branches of the economy, the number of public employees is highly overrepresented in agriculture (26605). It is a promising tendency that in the previous 2-3 years, the number of public employment programmes built on local specialities has remarkably increased (14248), with the second highest number of public employees working in the maintenance of local roads (9834) and in inland water management (7257).

The goal of the government in 2018 was to reduce the monthly average maximum number of public employees to 150,000 by 2020 . It is a change that people under the of 25 and with qualifications can only be involved in the programme if the labour mediation initiation of the authority failed three times because of the employer or the authority cannot provide a proper job within a three month period. The government tries to provide income to those youth who are under the age 25 and thereby exclude them from the public employment programme with jobs offered within the framework of the "Ifjúsági Garancia Program" (Guaranteeing Youth Programme), financed by the European Union. The figures prove that by 2017, the number of youth under the age of 25 has decreased to 19,000 in the public employment programme which is less by 6,000 in comparison with the previous year. It is a further goal that starting from June 2018, no one should be a public employee for more than 1 year within a three year time period, except in cases in which the private sector does not offer the individual a proper job. It is not easy to escape from the public employment programme, since it is not allowed to search for jobs when involved. The new government decision makes it possible to cover the jobsearch related expenses of public employees (Márk, 2017). 


\section{RESULTS AND DISCUSSION}

The available efficiency tests evenly prove that public employment programmes are the best in testing the willingness to work and the compulsory nature of the programme here is the most characteristic among all the active labour market programmes.

Analysing the efficiency of the public employment programme in Hungary (Aladi - Kulinyi, 2014), the so-called "deadweight-loss" has been revealed, meaning that one part of the participants could have found a job independently from the intervention. It means that the programme supported those unemployed people as well who did not really need it. On the other hand, the substitution effect is also present, which means that the subsidised positions and employees shrink other non-subsidised positions and employees (Csehné, 2007, 2018). Most positions produce low added value, and participation reduces the motivation and ability of the involved people to find jobs. Additionally, these programmes proved to be expensive and increase aiddependency.

A national survey (Cseres-Gergely - Molnár, 2014) revealed that while other active labour market programmes (education, financial support) encouraged entry to the open labour market, the public employment programme kept the new clients inside the programme. Long involvement in public employment is undoubtedly negatively related to entering the open labour market and positively to remaining outside of it. Thus, if someone is already involved in a public employment programme, his chance to leave it is bigger if his binding to the programme is looser. Most people are obstructed from searching for a job and from other income generating activities. The results of efficiency surveys revealed that the expenses of public employment reduce the application of active labour market programmes and the chance to get stuck is particularly high (Frey, 2007; Galasi - Nagy, 2008).

Among the positive effects, some experts mention the following: these programmes can provide participants with at least some temporary means of economic survival; they can contribute to the realisation of other development programmes; they can reduce poverty and inequality; they are suitable to activate disadvantaged groups, whose primary labour market integration seems to be impossible; they are suitable to overcome the challenges of structural unemployment and to ease the effects of economic crises.

Most employment opportunities are often provided by public employment programmes in rural areas (László, 2016; Koós, 2016; Váradi, 2016). Employment capacity of the primary labour market is extremely limited or is even missing in peripheral areas. Formal job opportunities disappeared in gipsy villages in the peripheral areas of the country, where the income of people living here depends entirely on family support, social transfers and public employment, in addition to the casual job opportunities which arise more by accident than by plan (Csoba, 2017; Virág, 2017). At the same time, there is not any other employment or "getting used to working" alternative for long term unemployed people (Risak - Kovacs, 2017). Additional arguments in favour of public employment programmes include their wage increasing effect, their social cohesion strengthening effect and their ability to provide up to date work experience.

Public employment originally was an active labour market programme ensuring temporary employment, but by now, it has become a job opportunity for almost all job seekers. Consequently, several new, subsidised positions requiring no special expertise have been created mainly in the agricultural sector in rural areas. Participation in the agricultural programme provides lower wages than the actual legal minimum wage, but these jobs are assured and have thus become one of the alternatives to seasonal work and having to resort to commuting (Uszkai, 2014; Koós, 2016; Kovacs, 2018).

\section{SUMMARY}

Active labour market programmes are effective only in those cases when, focusing on a certain problem, they provide reasonable and complex solutions. The Hungarian public employment programme is unique in Europe regarding the expenditures and the number of participants. It is the most important programme of employment policy after 2010, thus analysing its short and long term effects is an important task. Based on the efficiency test, national public employment programmes could not reduce long term unemployment. Public employment created a so-called second market, which can hamper economic development programmes. This inefficiency is in line with international experience and previous research findings concerning national public employment programmes. Experts agree that the most important goal is to avoid "getting stuck" in public employment. Unemployment and the resultant social exclusion is one of the greatest challenges of the 21st century. This is why it is important to rethink the concept of work and to develop new regulations.

\section{REFERENCES}

Adimassu, Z., Kessler, A. (2015): Impact of the productive safety net program on farmers' investments in sustainable land management in the Central Rift Valley of Ethiopia. Environmental Development, 16, pp. 54-62.

Aladi G., Kulinyi M. (2014): Közfoglalkoztatás hatékonyan. Budapest, Esély Labor, pp. 45-46.

Bankó Zoltán (2010): Az atipikus munkajogviszonyok. Dialóg Campus Kiadó, 224 p.

Besley, T., Coate, S. (1992): Workfare versus welfare: Incentive arguments for work requirements in poverty-alleviation programs. The American Economic Review, 82(1), pp. 249-261.

Brown, A. J., Koettl, J. (2015): Active labor market programsemployment gain or fiscal drain?. IZA Journal of Labor Economics, 4(1), 12.

Crépon, B., Van den Berg, G. J. (2016): Active labor market policies. Annual Review of Economics, 8, pp. 521-546. 
Csehné Papp I. (2007): A közhasznú foglalkoztatás jogi és humán vonatkozású változásai az utóbbi tíz évben, Munkaügyi Szemle. 4. pp. 15-19.

Csehné Papp I. (2018): A közhasznú foglalkoztatottak főbb jellemzôinek változása 20 éves idôtávban. Egy kistérségi kutatás eredményei. Munkaügyi Szemle. 2.

Csehné Papp I., Horesnyi J., Szellő J., Vincze I. (2009): Munkaerô-piaci ismeretek. Tanulmánykötet OFA - SZMMM - Szent István Egyetem Gazdaság és Társadalomtudományi Kar, (szerk. Csehné Papp I.; Horesnyi J.) Gödöllő, 86 p.

Cseh Papp I., Csapóné Riskó T. (2014): Historical overview of the Hungarian labour market, International Journal of Social Science, 1, pp 39-49.

Cseres-Gergely ZS., Molnár Gy. (2014): Munkapiaci helyzet a közfoglalkoztatásból való kilépés után. In: Munkaerőpiaci tükör, 2014. MTA Közgazdaság- és Regionális Tudományi Kutatóközpont Közgazdaság-tudományi Intézet, Budapest, pp.143153.

Csoba J. (2010): "Segély helyett munka" A közfoglalkoztatás formái és sajátosságai Szociológiai Szemle 20. pp. 26-52.

Csoba J. (2017): A kertkultúra és a háztartásgazdaság szerepe a vidéki szegények társadalmi integrációjában - 25 éves a Szociális Földprogram. Tér és Társadalom, 31 (3), pp. 85-102.

Csoba J., Nagy Z. (2011): A magyarországi képzési, bértámogatási és közfoglalkoztatási programok hatásvizsgálata In: Munkaerốpiaci tükör, 2011. MTA Közgazdaság- és Regionális Tudományi Kutatóközpont Közgazdaság-tudományi Intézet, Budapest, pp. 113-144.

Douarin, E., Mickiewicz, T. (2017): Unemployment and Labour Market Policies. In: Economics of Institutional Change. pp. 205-226

Eardley, T., Bradshaw, J., Ditch, J., Gough, I. és Whiteford, P. (1996): Social Assistance schemes in the OECD countries. Volume 1. Synthesis report, DSS Research Report 46, London: HMSO.

Frey M. (1995): A közhasznú foglalkoztatás munkaerôpiaci hatásai: Egy empirikus kutatás tanulságai. In: A jövő munkahelyeiért [1. köt.]. Bp.: Struktúra-Munkaügy, 1995.pp. 132-147.

Frey M. (2007): A közhasznú foglalkoztatás munkaerôpiaci hatásai, http://old.ektf.hu/ juhasz.istvan/human_erof_akt_k/Mu nkaerszázalékf5piaciszázalék20tszázalékfckszázalékf6r/2007/ frey.pdf. (approached: 01.06.2017)

Galasi P., Nagy Gy. (2008): Az aktív munkaerô-piaci programokba kerülés esélyei: képzés, bértámogatás, közhasznú munka. Budapest: MTA Közgazdaságtudományi Intézet; Budapesti Corvinus Egyetem, Emberi Erőforrások Tanszék BWP 2008/7. 30 p.

Godfrey, M., Lázár, Gy., O’Leary, C. (1993): Report on a Survey of Unemployment and Active Labour Market Programmes in Hungary. ILO/Japan Project on Employment Policies for Transition in Hungary. W.E. Upjohn Institute.

Grover, C., Stewart, J. (1999): Market workfare: Social Security, social regulation and competitiveness in the 1990s', Journal of Social Policy, vol 28, no 1, pp 73-96.

Heikkila, M., Hvinden, B., Kautto, M., Marklund, S., Ploug, N. (Eds.). (2002): Nordic social policy: changing welfare states. Routledge. 324 p.

Ismail, M. A. (2016): Globalization and new international public works agreements in developing countries: an analytical perspective. Routledge. 316. p.

Kálmán J. (2015): A közfoglalkoztatási programok háttere és nemzetközi tapasztalatai. In: Munkaerôpiaci tükör, 2014. MTA Közgazdaság- és Regionális Tudományi Kutatóközpont Közgazdaság-tudományi Intézet, Budapest, pp. 42-58.

Koós B. (2016): Közfoglalkoztatás a mezőgazdaságban. Tér és Társadalom 3. pp. 40-62.

László GY. (2016): A hátrányos helyzetúek foglalkoztatási nehézségei. Opus et Educatio, 3 (3).

Márk E.(2017): Indul a közfoglalkoztatás reformja, Világgazdaság. March 10. https://www.vg.hu/velemeny/indul-akozfoglalkoztatas-reformja-484623/ (approached: 01.06.2017)

Martin, J., Grubb, D. (2001): What Works and for Whom: A Review of OECD Countries' experiences with active labour market policies. $52 \mathrm{p}$.

Mourelo, E. L., Escudero, V. (2017): Effectiveness of Active Labor Market Tools in Conditional Cash Transfers Programs: Evidence for Argentina. World Development, 94, pp. 422-447.

Murgai, R., Ravallion, M., van de Walle, D. (2015). Is workfare cost-effective against poverty in a poor labor-surplus economy? The World Bank Economic Review, 30(3), 413-445.

OECD (2016), „Labour market programmes: expenditure and participants", OECD Employment and Labour Market Statistics (database), December.

Ravi, S., \& Engler, M. (2015). Workfare as an effective way to fight poverty: The case of India's NREGS. World Development, 67 , pp. 57-71.

Ronconi, L., Sanguinetti, J., \& Fachelli Oliva, S. (2006). Poverty and employability effects of workfare programs in Argentina. 43 p.

Rosas, N., Sabarwal, S. (2016): Public Works as a Productive Safety Net in a Post-Conflict Setting. 33 p.

Schmidt, F., Berger, E., Schunk, D., Müller, H., König, G. (2017). Self-Regulation Training and Job Search Effort: A Natural Field Experiment within an Active Labor Market Program.

Shah, M., Steinberg, B. M. (2015): Workfare and Human Capital Investment: Evidence from India (No. w21543). National Bureau of Economic Research. 38. p.

Smith, J. S. (2006): Building New Deal Liberalism: The Political Economy of Public Works, 1933-1956. Cambridge University Press

Szabó A. (2013): A közfoglalkoztatás, mint foglalkoztatápolitikai eszköz. Nagyerdei Almanach.2. pp. 149-161.

Uszkai A. (2014): Innováció és oktatás az élhetőbb vidékért. A Falu, 29 (2), pp. 75-85.

Váradi M (2016): Értékteremtô közfoglalkoztatás periferikus vidéki terekben. Esély 1 pp. 30-57

Virág T. (2017): A cigányfalu mint jelenség és értelmezési keret. Replika, 104 (4), pp. 45-62.

Wulfgramm, M. (2014): Life satisfaction effects of unemployment in Europe: The moderating influence of labour market policy. Journal of European Social Policy, 24(3), pp. 258-272.

Zieliński, M. (2015): Unemployment and labor market policy in Visegrad Group countries. Equilibrium. Equilibrium. Quarterly Journal of Economics and Economic Policy,10 (3), pp. 185-201. 
